\title{
Synthesis of Rice Husk Mesoporous Silica as pH Responsive Release Material
}

\author{
Pidia Aulia, Saprini Hamdiani, Iwan Sumarlan \\ Department of Chemistry, Faculty of Mathematics and Natural Science, University of Mataram. Jalan \\ Majapahit No. 62 Mataram 83125 Indonesia. \\ *Email: saprini.h@unram.ac.id
}

Received February 2019; Accepted Augustus, 2019

\begin{abstract}
The synthesis of mesoporous silica as a delivery agent for the ethyl para-methoxycinnamate has been carried out. The study aims to determine the process of mesoporous silica synthesis from sodium silicate from the smelting of rice husk ash, determine the adsorption capacity of mesoporous silica in the ethyl paramethoxycinnamate and the $\mathrm{pH}$ responsive release of ethyl para-methoxycinnamate with mesoporous silica as a delivery agent in simulated intestinal and gastric fluids. It was found that mesoporous silica can be synthesized from rice husk ash with a $30 \%$ tartaric acid template. Characterization of mesoporous silica using FTIR spectroscopy showed the presence of silanol ( $\mathrm{Si}-\mathrm{OH})$ and siloxane (Si-O-Si) functional groups. Mesoporous silica from rice husk ash is able as adsorbent for the ethyl para-methoxycinnamate with the adsorption capacity of $8.26 \mathrm{mg} / \mathrm{g}$. The release test of gastric simulation fluid $(\mathrm{pH} 1.2)$ showed that the ethylpara-methoxycinnamate was released from silica for a period of 12 hours. In the intestinal simulation fluid $(\mathrm{pH} 7.4)$, the release of the ethyl para-methoxycinnamate occurred slowly at the first hour, then gradually increased at 5 hour up to 12 hour.
\end{abstract}

Keywords: mesoporous silica, rice husk ash, adsorption, ethyl para-methoxycinnamate, release test

\section{INTRODUCTION}

Free radicals have a bad influence on the body. The effects of free radical reactivity include cell and tissue damage, autoimmune diseases, degenerative diseases, to cancer. Consuming antioxidants is a solution to overcome the negative effects of free radicals in the body [1-4]. The ethyl para-methoxycinamat from the kencur kencur plant is a good antioxidant [5-6]. These antioxidants are expected to be delivered efficiently to the body. The adsorption method using mesoporous silica filled with ethyl methoxy cinnamon can be used. The capacity of mesoporous silica adsorption can increase the interaction between the adsorbent and ethyl paramethoxycinamic so that it can be used as an agent for delivering antioxidant compounds.

In this study, silica gel was made from rice husk ash as a delivery agent. Waste from rice husk ash is usually not utilized maximally so that it can cause environmental pollution. The most dominant chemical compound in rice husk ash is silica which is $72.28 \%$ [7-8]. Therefore, silica from rice husk ash are utilized and modified into mesoporous silica for use as an adsorbent [9-10]. Thus, the purpose of this research is to find out the process of mesoporous silica synthesis from sodium silicate from the smelting of rice husk ash with tartaric acid template, to determine the adsorption capacity of mesoporous silica in the ethyl para-methoxycinamic compound, and to determine the release of ethyl paramethoxycinamic with mesoporous silica as a material of mesoporous silica adsorption on the ethyl para-methoxycinamic compound, and to determine the release of ethyl paramethoxycinamic with mesoporous silica as the material carrier on simulating intestinal and gastric fluids.

\section{METHODOLOGY \\ Tools and chemical}

The characterization instruments in this study were infrared spectrophotometers (Shimadzu FTIR-8201 PC), UV-Vis spectrophotometers (Shimadzu) with additional devices in the form of magnetic stirrers, ovens (Fischer Scienific), analytical scales (Vibra AJ-1200E), heating furnaces, cups porcelain, grinding tools (lumping 40 and mortar), vacuum pumps.

The research materials include rice husk as a source of silica; tartaric acid (Merck), distilled water, $4 \mathrm{M} \mathrm{NaOH}, 3 \mathrm{M} \mathrm{HCl}, 0.1 \mathrm{M} \mathrm{NaOH}, 0.1 \mathrm{M} \mathrm{HCl}$, $\mathrm{pH}$ 7,4 buffer solution, pH 1.2 buffer solution, universal $\mathrm{pH}$ indicator paper, filter paper and Whattman filter paper no . 42

\section{Research procedure}

Rice husk being used was originating from central Lombok, Indonesia. It was cleaned from other mixes such as twigs and leaves and burned 
evenly until ash was formed. The husk ash that has been formed was then crushed and sieved. The making of $\mathrm{Na} 2 \mathrm{SiO} 3$ from rice husk ash in this study followed the procedure carried out by our previous study [11-12]. A total of $20 \mathrm{~g}$ of rice husk ash sample was added with $200 \mathrm{~mL}$ of $4 \mathrm{M} \mathrm{NaOH}$, then heated to boiling while stirring with a magnetic stirrer. After thickening and the solution is black, the solution is poured into a porcelain cup and melted at a temperature of $500 \mathrm{oC}$ for 30 minutes. After cooling, the solution was added with $200 \mathrm{~mL}$ of distilled water, left overnight and filtered with Whatman filter paper no. 42. The resulting filtrate is a solution of sodium silicate (Na2SiO3) which is ready to be used as a material for making silica adsorbents.

\section{The sol-gel process of making mesoporous silica with the tartaric acid.}

A total of $20 \mathrm{~mL}$ of sodium silicate compound resulting from the smelting of rice husk ash was put into a plastic container, then added the tartaric acid template. Furthermore, $0.1 \mathrm{M} \mathrm{HCl}$ and $0.1 \mathrm{M} \mathrm{NaOH}$ were added dropwise while stirring with a magnetic stirrer to form a gel and continued until a neutral solution $(\mathrm{pH} 7)$. The gel formed is allowed to stand overnight, washed with distilled water until it is neutral against the universal indicator, and dried in an oven at $70 \mathrm{oC}$. After drying, crushed and sieved with 200 mesh sieve. The silica obtained was characterized by FTIR.

A ethyl para-methoxycinnamate release test on the simulation of gastric and intestinal fluids in this study followed the procedure carried out [13-14]. Drug release was carried out by immersing a number of mesoporous silica samples with the para-methoxycinamic ethyl compound with the highest amount of mesoporous silica in $50 \mathrm{~mL}$ buffer solution at $\mathrm{pH}$ 1.2 (simulated gastric fluid) and at $\mathrm{pH} 7.4$ (simulated intestinal fluid). A buffer of $\mathrm{pH} 1.2$ was prepared by mixing $250 \mathrm{~mL}$ of $\mathrm{HCl} 0.2 \mathrm{M}$ and 147 $\mathrm{mL} \mathrm{KCl} 0.2 \mathrm{M}$, while a buffer solution of $\mathrm{pH} 7.4$ was made by mixing $250 \mathrm{~mL} \mathrm{KH2PO} 40.1 \mathrm{M}$ and $195.5 \mathrm{~mL} \mathrm{NaOH} 0.1 \mathrm{M}$. The mixture is stirred at $300 \mathrm{rpm}$ using magnetic stirrer at $370 \mathrm{o}$. Every 1 hour interval, $5 \mathrm{~mL}$ samples are taken and replaced with the same buffer volume. The samples taken were then filtered, and their concentration measured using a UV-Vis spectrophotometer at a wavelength of $350 \mathrm{~nm}$. This drug release test is carried out over a 12 hour period.

\section{RESULTS AND DISCUSSION}

Characterization of mesoporous silica carried out in this study is chemical characterization by identifying functional groups contained in mesoporous silica using FTIR instruments. The results of the characterization of mesoporous silica powder using FTIR are shown in Table1. The absorption of Si-O functional groups in silica gel is shown in the dominant wave number at wavelengths $1091.84 \mathrm{~cm}-1,958.36 \mathrm{~cm}$ $1,796.07 \mathrm{~cm}-1$ and $466.86 \mathrm{~cm}-1$. There is a bending vibration of siloxane at the wave number $466.86 \mathrm{~cm}-1$. Vibration of stretching Si-O from siloxane was shown by absorption band at wave number $796.07 \mathrm{~cm}-1$. The stretching vibration of $\mathrm{Si}-\mathrm{O}$ silanol is shown by the absorption at the wave number $958.36 \mathrm{~cm}-1$. The strong absorption band at wave number $1091.84 \mathrm{~cm}^{-1}$ is the symmetric stretching vibration of $\mathrm{Si}-\mathrm{O}$ from siloxane (Si-O-Si). At the wave number 1638.41 $\mathrm{cm}^{-1}$ there was absorption from the vibration vibrations of $\mathrm{O}-\mathrm{H}$ silanol, and at wave number $3467.1 \mathrm{~cm}^{-1}$ there was absorption from the stretching vibrations of $\mathrm{O}-\mathrm{H}$ silanol. In general, the absorption bands that appear in silica gel spectra indicate that the functional groups found in silica gel produced from rice husk ash are silanol (Si$\mathrm{OH}$ ) and siloxan ( $\mathrm{Si}-\mathrm{O}-\mathrm{Si}$ ) groups.

In silica gel with the addition of tartaric acid, the sharp band at $3400.81 \mathrm{~cm}^{-1}$ is caused by not forming hydrogen bonds in the interaction between mesoporous silica and tartaric acid. The strong and characteristic band at $1735.2 \mathrm{~cm}-1$ indicates the presence of the $\mathrm{C}=\mathrm{O}$ carbonyl group of tartaric acid. The addition of tartaric acid also increased the intensity of the asymmetric stretching of Si-O from the siloxan group which is $1083.11 \mathrm{~cm}-1$ compared to silica gel. This is probably caused by the transfer of electron $O$ atoms from the carboxyl group or silanol group, can attack $\mathrm{Si}$ atoms from mesoporous silica to form $\mathrm{Si}-\mathrm{O}-\mathrm{Si}$. This also shows that there has been an increase in the intensity of silanol groups and the formation of siloxane bonds (Si-O-Si). For mesoporous silica with the tartaric acid template that has been removed by the solvent extraction method, there is a shift in the wave number for the siloxane ( $\mathrm{Si}-\mathrm{O}-\mathrm{Si}$ ) bond to $1055.31 \mathrm{~cm}^{-1}$. This shows the siloxane binding energy decreases, so that the bond between the antaratomes weakens and results in the breaking of the Si-O-Si bond between the surfaces of the mesoporous silica with the surface of the tartaric acid. In addition, the characteristic absorption of $\mathrm{C}=\mathrm{O}$ carbonyl group from tartaric acid at $1735.2 \mathrm{~cm}-1$ and sharp bands in the area of about $1132.81 \mathrm{~cm}-1$ which is the wave number for the $\mathrm{C}-\mathrm{O}$ bond has no longer appeared. This shows that the tartaric acid template has been successfully removed from mesoporous silica. 
Table 1 FTIR absorption bands and wave numbers (a) Silica Gel, (b) Silica Gel with Addition of Tartaric Acid and (c) Mesoporous Silica

\begin{tabular}{ccccccccc}
\hline & Silica Gel & \multicolumn{3}{c}{ Silica Gel with Tartaric acid } & \multicolumn{3}{c}{ Mesoporic silica } \\
\hline $\begin{array}{c}\text { current } \\
\text { study } \\
\left(\mathrm{cm}^{-1}\right)\end{array}$ & $\begin{array}{c}\text { Referen } \\
\text { ce [14] } \\
\left(\mathrm{cm}^{-1}\right)\end{array}$ & & $\begin{array}{c}\text { current } \\
\text { study } \\
\left(\mathrm{cm}^{-1}\right)\end{array}$ & $\begin{array}{c}\text { Reference } \\
{[15]} \\
\left(\mathrm{cm}^{-1}\right)\end{array}$ & $\begin{array}{c}\text { current } \\
\text { study } \\
\left(\mathrm{cm}^{-1}\right)\end{array}$ & $\begin{array}{c}\text { Reference } \\
{[15]}\end{array}$ \\
$\left(\mathrm{cm}^{-1}\right)$
\end{tabular}

Table 2 shows that there was a shift in mesoporous silica wave numbers before and after adsorption. The wave number shift occurs in the $\mathrm{Si}-\mathrm{OH}$ functional group and the Si-O group where the percent transmittance increases after the adsorption process. This is in accordance with the Lambert-Beer law which states that transmittance is inversely proportional to absorbance and concentration [16]. The shift of the wave number after adsorption indicates that the paramethoxycinamic ethyl compound has been adsorbed by the adsorbent. The formation of a bond between the adsorbent and the paramethoxycinamic ethyl compound will cause the vibrational motion of the adsorbent structure to become stiffer so that the resulting frequency is lower.

Table 2 Comparison of FTIR waveform data before and after adsorption

\begin{tabular}{ccccc}
\hline & \multicolumn{2}{c}{ adsorpstion } & \multicolumn{2}{c}{ after adsorpstion } \\
\cline { 2 - 5 } & $\begin{array}{c}\text { Wave numbers } \\
\left(\mathrm{cm}^{-1}\right)\end{array}$ & Transmitan $(\%)$ & $\begin{array}{c}\text { Wave Numbers } \\
\left(\mathrm{cm}^{-1}\right)\end{array}$ & Transmitan (\%) \\
\hline Si-OH & 3400.81 & 0.59 & 3466.73 & 4.64 \\
Si-O & 1055.31 & 1.59 & 960.77 & 6.67 \\
\hline
\end{tabular}

\section{Adsorption}

The para-methoxycinamic ethyl adsorption level was based on the influence of $\mathrm{pH}$, concentration and contact time. The optimum $\mathrm{pH}$ was obtained at $\mathrm{pH} 9$ with an adsorption capacity value of $2.35 \mathrm{mg} / \mathrm{g}$, the optimum concentration was obtained at a concentration of $9 \mathrm{ppm}$ with an adsorption capacity value of $8.265 \mathrm{mg} / \mathrm{g}$ and the optimum contact time was obtained at 30 minutes with an adsorption capacity value of $8.494 \mathrm{mg} / \mathrm{g}$. The suitable isotherm model is the Freundlich isotherm model which means that the absorption of the para-methoxycinamic ethyl occurs physically. 


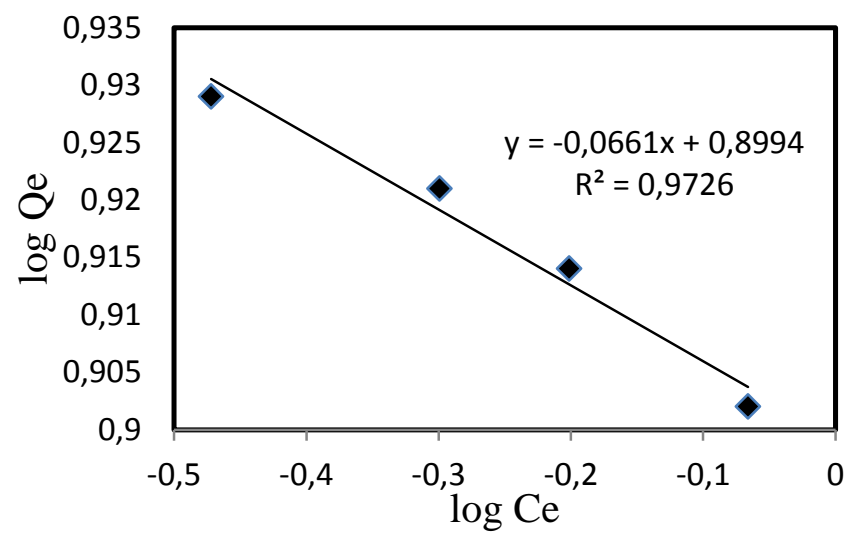

Figure 1 Freundlich isotherm curve

Figure 1 shows the comparison of the R2 values in the Freundlich isotherm. Values are calculated based on the results of the adsorption capacity and concentration on the effect of contact time. The isotherm model that fits the research data is tested using simple linear regression analysis by looking at the correlation coefficient (R2). If the value of $R 2$ is getting closer to 1 then it can be said that there is a greater influence and the relationship between variables is getting stronger [17]. In this study, the value of $R 2$ in the Freundlich isotherm is closer to 1 compared to R2 in the Langmuir isotherm. This shows that in this study the Freundlich isotherm is used, which means that the absorption of the ethyl paramethoxycinamic compound that occurs is physical. The Freundlich isotherm model assumes that the adsorbent has a heterogeneous surface and each molecule has different application potentials and the assumption that the adsorption occurs multilayer on the surface of the adsorbent.

\section{Adsorption kinetics}

Determination of the mechanism and rate of adsorption can be determined by the kinetic model approach. One of the main objectives of adsorption kinetics research is to determine a suitable model for the adsorption kinetics of paramethoxycinamic ethyl compounds, and to obtain the values of the adsorption kinetics parameters. The kinetics of adsorption of para-methoxycinamic ethyl compounds by adsorbents can be determined by processing the adsorption results data on the influence of the contact time on the adsorption capacity value.

Table 3 Data from the determination of the adsorption kinetics model

\begin{tabular}{ccc}
\hline Kinetics Model & Parameters & Parameter Values \\
\hline Orde I & $\mathrm{R}^{2}$ & 0.99112 \\
& $\mathrm{~K}\left(\right.$ minute $\left.^{-1}\right)$ & $53,8 \times 10^{-3}$ \\
\hline Orde II & $\mathrm{R}^{2}$ & 0.9997 \\
& $\mathrm{~K}\left(\right.$ minute $\left.^{-1}\right)$ & $82,9 \times 10^{-3}$ \\
\hline Pseudo orde I & $\mathrm{R}^{2}$ & 1 \\
& $\mathrm{~K}\left(\right.$ minute $\left.^{-1}\right)$ & $115610,6 \times 10^{-6}$ \\
\hline \multirow{2}{*}{ Pseudo orde II } & $\mathrm{R}^{2}$ & 1 \\
& $\mathrm{~K}\left(\mathrm{~g}^{-m^{-1}}\right.$ minute $\left.^{-1}\right)$ & 0,06250 \\
\hline
\end{tabular}

Therefore it can be concluded that mesoporous silica adsorbs para-methoxycinamic ethyl compounds both chemically and physically. Physical adsorption is proven by the isotherm model to describe the adsorption that occurs, namely the Freundlich isotherm model. The Freundlich model which states the adsorption of para-methoxycinamic ethyl by mesoporous silica 
occurs physically and forms a multilayer layer. The results of the calculation of the adsorption kinetics model with the results of the kinetics model occurred in pseudo order II and II which meant that the adsorption process occurred physically and chemically. Chemical adsorption is also evidenced by the shift in wave numbers and the increase in transmittance value in the FTIR mesoporous silica after adsorption [18-21].

\section{In vitro $\mathrm{pH}$ release test}

Figure 2 and 3 show the pattern of paramethoxycinamic ethyl release in a simulated gastric fluid made with a $\mathrm{pH}$ of 1.2 . It can be seen that there is no release of para-methoxycinamic ethyl at that $\mathrm{pH}$ for a period of 12 hours. This indicates the strong interaction of ethyl paramethoxycinamic with mesoporous silica at this $\mathrm{pH}$. At acidic $\mathrm{pH}$, mesoporous silica active sites are protonated and cause these active sites to be positively charged. This causes the drug to remain trapped in the silica framework. These results can give an idea, that the para-methoxycinamic ethyl is not absorbed in the stomach, as a result the bioavailability of ethyl para-methoxycinamic in the blood can be high.

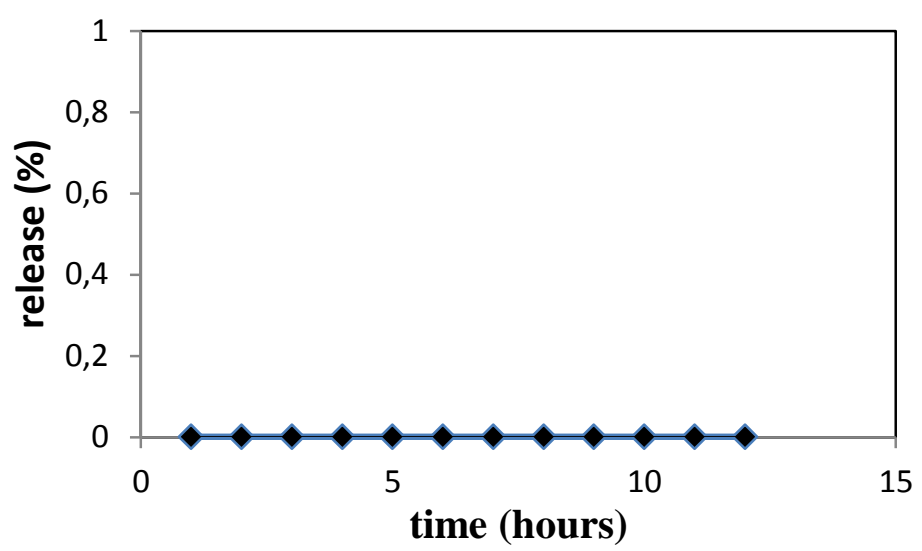

Figure 2. Pattern of para-methoxycinamic ethyl release in a simulated gastric fluid

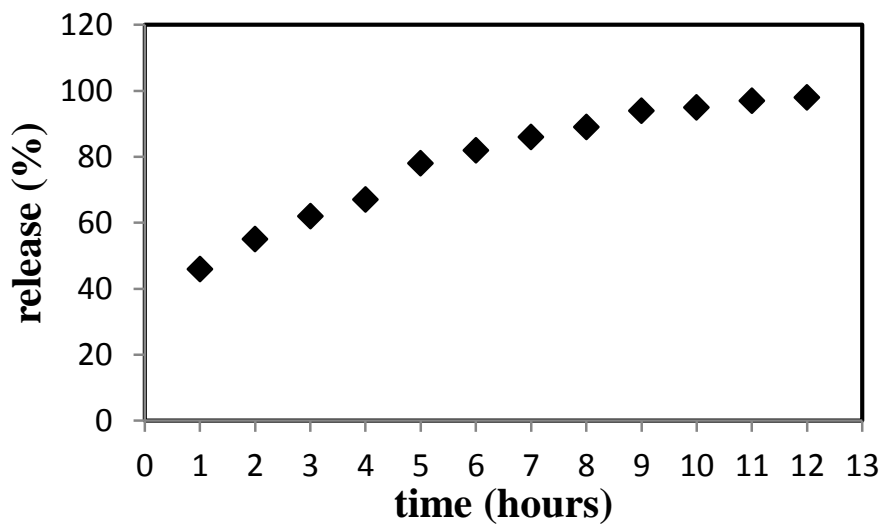

Figure 3. Pattern of para-methoxycinamic ethyl release in a simulated intestinal fluid

In the intestinal simulation fluid ( $\mathrm{pH} 7.4)$, the release of para-methoxycinamic ethyl occurs slowly in the first 4 hours (Figure 3 ). The release of para-methoxycinamic ethyl occurs because the total surface charge of mesoporous silica becomes neutral. At neutral surfaces no bonding occur between mesoporous silica and ethyl paramethoxycinamic so that there is release of intestinal simulation fluid. Drug release occurs and then slowly decreases until the 12th hour. This is because the amount of para-methoxycinamic ethyl bound to mesoporous silica decreases. The function of using a buffer solution in the stomach and intestine simulation is to maintain the $\mathrm{pH}$. The buffer system is in the form of a weak acid with a conjugate base or vice versa a weak base with a conjugate acid. To simulate the $\mathrm{pH}$ in the stomach and intestine, the buffer solution is used.

\section{CONCLUSION}


Based on the data and discussion of test results in this study, some conclusions can be drawn as follows:

(1) Mesoporous silica can be synthesized from sodium silica from the smelting of rice husk ash through the sol gel process by the addition of a tartaric acid template.

(2) The para-methoxycinamic ethyl compound has an adsorption level based on the influence of $\mathrm{pH}$, concentration and contact time. The optimum $\mathrm{pH}$ was obtained at $\mathrm{pH} 9$ with an adsorption capacity value of $2.35 \mathrm{mg} / \mathrm{g}$, the optimum concentration was obtained at a concentration of $9 \mathrm{ppm}$ with an adsorption capacity value of $8.265 \mathrm{mg} / \mathrm{g}$ and the optimum contact time was obtained at 30 minutes with an adsorption capacity value of $8.494 \mathrm{mg} / \mathrm{g}$. The suitable isotherm model is the Freundlich isotherm model which means that the absorption of the para-methoxycinamic ethyl compound occurs physically.

(3) The release of para-methoxycinamic ethyl compound in gastric simulation fluid ( $\mathrm{pH} \mathrm{1.2)}$

shows that the para-methoxycinamic ethyl compound is not separated from silica for a period of 12 hours, whereas in intestinal simulation fluid (pH 7.4), release The para-methoxycinamic ethyl compound occurs slowly every hour until the 12th hour.

\section{References}

[1] Young, A. J., \& Lowe, G. M. (2001). Antioxidant and prooxidant properties of carotenoids. Archives of Biochemistry and biophysics, 385(1), 20-27.

[2] Pisoschi, A. M., \& Negulescu, G. P. (2011). Methods for total antioxidant activity determination: a review. Biochem Anal Biochem, 1(1), 106.

[3] Shahidi, F., \& Ambigaipalan, P. (2015). Phenolics and polyphenolics in foods, beverages and spices: Antioxidant activity and health effects-A review. Journal of functional foods, 18, 820-897.

[4] Chowdhury, M. Z., Al Mahmud, Z., Ali, M. S., \& Bachar, S. C. (2014). Phytochemical and pharmacological investigations of rhizome extracts of Kaempferia galanga. Int J Pharmacogn, 1(3), 185-192.

[5] Sahoo, S., Parida, R., Singh, S., Padhy, R. N., \& Nayak, S. (2014). Evaluation of yield, quality and antioxidant activity of essential oil of in vitro propagated Kaempferia galanga Linn. Journal of Acute Disease, 3(2), 124-130.

[6] Chan, E. W. C., Lim, Y. Y., Wong, L. F., Lianto, F. S., Wong, S. K., Lim, K. K., ... \& Lim, T. Y. (2008). Antioxidant and tyrosinase inhibition properties of leaves and rhizomes of ginger species. Food chemistry, 109(3), 477-483.

[7] Della, V. P., Kühn, I., \& Hotza, D. (2002). Rice husk ash as an alternate source for active silica production. Materials letters, 57(4), 818-821.

[8] Malhotra, V. M. (1993). Fly ash, slag, silica fume, and rice husk ash in concrete: a review. Concrete International, 15(4), 2328.

[9] Manique, M. C., Faccini, C. S., Onorevoli, B., Benvenutti, E. V., \& Caramão, E. B. (2012). Rice husk ash as an adsorbent for purifying biodiesel from waste frying oil. Fuel, 92(1), 56-61.

[10] Kumar, S., Sangwan, P., Dhankhar, R. M. V., \& Bidra, S. (2013). Utilization of rice husk and their ash: A review. Res. J. Chem. Env. Sci, 1(5), 126-129.

[11] Miftiyati, S., Hamdiani, S., \& Darmayanti, M. (2018). Synthesis Of Paramagnetic Merkapto Silica Hybrid From Rice Husk Ash For Ag(I) Adsorben. Acta Chimica Asiana, 1(2), 30-36.

[12] Antoni, W., Hamdiani, S., \& Kamali, S. (2019). Thermodynamics and Kinetics of Adoption of Ag (I) on Paramagnetic Silica Rice Husk Ash Surface. Acta Chimica Asiana, 2(1), 69-74.

[13] Charnay, C., Bégu, S., Tourné-Péteilh, C., Nicole, L., Lerner, D. A., \& Devoisselle, J. M. (2004). Inclusion of ibuprofen in mesoporous templated silica: drug loading and release property. European Journal of Pharmaceutics Biopharmaceutics, 57(3), 533-540.

[14] Yoo, S. H., Song, Y. B., Chang, P. S., \& Lee, H. G. (2006). Microencapsulation of $\alpha$ tocopherol using sodium alginate and its controlled release properties. International journal of biological macromolecules, 38(1), 25-30. 
[15] Mujiyanti, D.R., Nuryono, Kunarti, E.S (2010). Sintesis Dan Karakterisasi Silika Gel Dari Abu Sekam Padi Yang Dimobilisasi Dengan 3-(Trimetoksisilil)-1Propantiol. J. Sains dan Terapan Kimia. 4. 2. hlm 150-167.

[16] Hamdiani, S., Nuryono, N., \& Rusdiarso, B. (2015). Kinetika Adsorpsi Ion Emas (lii) Oleh Hibrida Merkapto Silika. Jurnal Pijar Mipa, 10(1).

[17] Rusdiarso, B., Kunarti, E. S., \& Hamdiani, S. (2008). Synthesis of Mesoporous MethylSilica Hybrid for Adsorption of Alizarin Reds. Indonesian Journal of Chemistry, 8(2), 193-199.

[18] Wulandari, R., Hamdiani, S., \& Ismillayli, N. (2019). Synthesis Of Mesoporiic Silica From Rice Husk Ash For Pinostrobin Based Drug Delivery. Acta Chimica Asiana, 2(1), 75-82.

[19] Anene, A., Kalfat, R., Chevalier, Y., \& Hbaieb, S. (2016). Molecularly imprinted polymer-based materials as thin films on silica supports for efficient adsorption of Patulin. Colloids and Surfaces A: Physicochemical and Engineering Aspects, 497, 293-303.

[20] Ngah, W. W., Teong, L. C., \& Hanafiah, M. A. K. M. (2011). Adsorption of dyes and heavy metal ions by chitosan composites: A review. Carbohydrate polymers, 83(4), 1446-1456.

[21] Chuah, T. G., Jumasiah, A., Azni, I., Katayon, S., \& Choong, S. T. (2005). Rice husk as a potentially low-cost biosorbent for heavy metal and dye removal: an overview. Desalination, 175(3), 305-316. 